\title{
SEX-SPECIFIC ANDROGEN BINDING IN SPOTTED HYAENA (CROCUTA CROCUTA) PLASMA
}

\author{
A. S. van JaArsveld, R. J. van Aarde, ${ }^{*}$ J. D. Skinner and V. van Wyk \\ Mammal Research Institute, University of Pretoria, Pretoria 0002, South Africa, Tel.: (012) 420-2066;
} Fax: (012) 43-2185

(Received 27 Jamuary 1992)

\begin{abstract}
A charcoal adsorption assay demonstrated a large variance in androgen binding ability in female spotted hyaenas.

2. A positive correlation between plasma androgen binding ability and ovarian steroid concentrations was demonstrated in adult females.

3. The strong plasma binding affinity for testosterone and dihydrotestosterone (DHT) (nM) together with the lack of cortisol and weaker oestradiol-17 $\beta$ binding suggests that a specific androgen binding substance, possibly a protein, is present in adult females of this species.

4. The lack of high affinity binding in male spotted hyaenas is unusual and deserves further investigation.

5. Some androgen binding in all, including males and immature animals suggests that albumin may bind some plasma androgens in this species.
\end{abstract}

\section{INTRODUCTION}

The spotted hyaena (Crocuta crocuta) is a social carnivore that lives in clans (Kruuk, 1972). Females are philopatric and males disperse at puberty in order to gain mating rites (Henschel and Skinner, 1987). Females are generally dominant over males (Kruuk, 1972) and, consequently, males may be severely harrassed or even killed before finally being accepted into a target clan (Henschel and Skinner, 1987). Numerous aspects of spotted hyaena life history that can be considered unusual for a mammalian species, have been attributed to unexpected patterns of androgen secretion in females. These include the presence of male-like external genitalia in females (Lindeque and Skinner, 1982), precociality and female dominance (Racey and Skinner, 1979). The original inability to distinguish between the sexes using plasma androgen concentrations from adult animals, led to the suggestion that high peripheral androgens in females were responsible for female dominance (Racey and Skinner, 1979; Frank et al., 1985). Subsequently, comparative data obtained from other hyaenids and changes in androgen secretion during the social development of the spotted hyaena demonstrated that female dominance could not be attributed to high female androgen concentrations (Van Jaarsveld and Skinner, 1987). Thus, the inability of earlier reports to distinguish between the sexes using plasma androgen concentrations, is the result of depressed androgen concentrations in most adult males, and not due to increased androgen concentrations in adult females (Van Jaarsveld and Skinner, 1991a). This pattern was attributed to social suppression of male androgens in a female dominated society, with only those males that have successfully been accepted into a target clan after dispersal achieving significant androgen concentrations (Van Jaarsveld and Skinner, 1991a).

*To whom all correspondence should be addressed.
Thus far, only total androgen concentrations have been determined in this species, and sex-specific differences attributable to other variables which could influence androgen expression, such as the binding of androgens to plasma proteins, have not been investigated. The aims of the present study were to investigate the social, reproductive and endocrine correlates of plasma testosterone binding, and to illustrate the presence of a plasma substance with a high affinity for androgens.

\section{MATERIALS AND METHODS}

\section{Animals and blood samples}

Twenty-seven spotted hyaenas (Crocuta crocuta) with known social histories were immobilized with Zoletil following Van Jaarsveld (1988), between 1984 and 1987. Animals emanated from the Kruger National Park, the Kalahari Gemsbok National Park, and the National Zoological Garden populations in southern Africa. Animals were categorized into social categories following Henschel and Skinner (1987) and reproductive categories according to Matthews (1939). Blood samples were collected as described by Van Jaarsveld and Skinner (1991b) and plasma was stored at $-20^{\circ} \mathrm{C}$ until assayed.

\section{Hormone assays}

Hormone assays, specifications and validations have all been published previously. Plasma testosterone concentrations were assayed following Van Aarde and Skinner (1986), androstenedione following Van Jaarsveld and Skinner (1991a), oestradiol-17 $\beta$ and progesterone according to Van Jaarsveld et al. (1992).

\section{Plasma testosterone binding}

The ability of substances in plasma to bind testosterone in at least three animals belonging to those categories which provide the highest resolution (i.e. reproductive categories for females and social categories for males) were investigated using a charcoal adsorption assay (Fenske, 1990). To duplicate plasma samples $(200 \mu 1),[1,2,6,7$. ${ }^{3} \mathrm{H}$ ]testosterone (sp. act. $349 \mathrm{mCi} / \mathrm{mg}$; Radiochemical Centre, Amersham, U.K.) was added in $0.1 \mathrm{ml}$ phosphate 
buffer $(\sim 10,000$ c.p.m.). After mixing, tubes were incubated at $37^{\circ} \mathrm{C}$ for $60 \mathrm{~min}$ and at $4^{\circ} \mathrm{C}$ for a further $30 \mathrm{~min}$. Separation of plasma-bound and free testosterone was carried out at $4^{\circ} \mathrm{C}$ by adding $0.75 \mathrm{ml}$ dextran-coated charcoal consisting of a suspension of charcoal (Aktivole; Merck, Darmstadt, F.R.G.) in assay buffer $(0.156 \mathrm{~g} / \mathrm{ml})$ containing $0.0156 \mathrm{~g}$ Dextran T-40 (Pharmacia, Uppsala, Sweden) to each tube. After mixing gently for $20 \mathrm{sec}$, tubes were incubated at $4{ }^{\circ} \mathrm{C}$ for $10 \mathrm{~min}$ and centrifuged at the same temperature at $1500 \mathrm{~g}$ for $10 \mathrm{~min}$. The supernatants were decanted into scintillation vials followed by the addition of $4 \mathrm{ml}$ scintillation fluid (Scintillator 299 ${ }^{\mathrm{TM}}$; Packard Instrument Co., IL, U.S.A.). Recovered counts were taken to represent plasma binding. Corroboration of this assumption was provided by subjecting serial dilutions $(1: 0-1: 16)$ of the same plasma samples in phosphate buffer to the same procedure.

\section{Binding protein concentration}

One sample each from a parous female ( $86 \%$ binding) and a mating male ( $38 \%$ binding) were used to further investigate plasma binding. After thawing, plasma was centrifuged ( $1500 \mathrm{~g}$ for $5 \mathrm{~min}$ at $4^{\circ} \mathrm{C}$ ) and the precipitate discarded. Protein concentrations were determined by ultraviolet $a b$ sorbance at $280 \mathrm{~nm}$ using a Hitachi U-2000 spectrophotometer (Tokyo, Japan).

\section{Androgen binding activity}

Binding studies were conducted using a miniature equilibrium dialysis method similar to that of Reinard and Jacobsen (1989). Test cells were prepared using Eppendorf microtubes (Kartell-Africa, Johannesburg, South Africa) as described by Reinard and Jacobsen (1989). [1,2,6,7 ${ }^{3} \mathrm{H}$ Testosterone (Code TRK 402, spec. act. $98 \mathrm{Ci} / \mathrm{mmol}$ ) and dihydro $\left[1,2,4,5,6,7-{ }^{3} \mathrm{H}\right]$ testosterone (Code TRK 443, spec. act. $50 \mathrm{Ci} / \mathrm{mMol}$ ) obtained from Radiochemical Centre (Amersham, U.K.) were diluted in $0.01 \mathrm{M}$ Tris- $0.15 \mathrm{M} \mathrm{NaCl}$ buffer ( $\mathrm{pH}=7.4$; Tris- $\mathrm{NaCl}$ buffer) to a final concentration of approximately $15 \mathrm{nM}$. Aliquants $(250 \mu 1)$ of one of the radioactive ligands $\left({ }^{3} \mathrm{H}\right]$ testosterone or $\left[{ }^{3} \mathrm{H}\right] \mathrm{DHT}, 15 \mathrm{nM}$ ) was placed into the lower chamber of the test cell. A damp dialysis membrane was placed over the chamber and the test cell assembled. After assembly, $250 \mu \mathrm{l}$ of appropriately diluted plasma (200-fold) in Tris- $\mathrm{NaCl}$ buffer was added through the hole into the upper chamber (total binding). Competitive binding was determined in separate sets of tubes through the addition of increasing concentrations $\left(1 \times 10^{-12}\right.$ to $\left.1 \times 10^{-5} \mathrm{M}\right)$ of unlabelled dihydrotestosterone, $(5 \alpha$-androstan-17 $\beta$-ol-3-one $)$, testosterone (4-androsten-17 $\beta$-ol-3-one), oestradiol-17 $\beta$ (1,3,5(10)-estratriene-3,17 $\beta$-diol), cortisol (1 $1 \beta, 17,21$-trihydroxy-4-pregnene-3,20-dione) and progesterone (4-pregnene-3,20-dione), supplied by Sigma Chemical Company (St Louis, MO, U.S.A.), to the lower chamber of the cell containing $15 \mathrm{nM}$ tritiated ligand. Assembled test cells were incubated in a humid chamber at $4^{\circ} \mathrm{C}$ for $24 \mathrm{hr}$ after which $50 \mu 1$ aliquants from both chambers were collected and transferred to scintillation vials (Packard Instrument Co., Johannesburg, South Africa). Scintillation fluid (4 ml; Packard Instrument Co.) was added to each tube and radioactivity detected after $4 \mathrm{hr}$ using a Packard 1500 TRi-Carb scintillation counter (Packard Instrument Co., IL, USA). All binding experiments were conducted in triplicate. The competitive efficiency of various steroids was compared to that determined for unlabelled testosterone or DHT using the following equation:

$$
\begin{aligned}
& \text { B with }\left[{ }^{3} \mathrm{H}\right] \text { ligand alone } \\
& \frac{- \text { B with }\left[{ }^{3} \mathrm{H}\right] \text { ligand and competing steroid }}{\text { B with }\left[{ }^{3} \mathrm{H}\right] \text { ligand alone }} \\
& \quad \text { - B with }\left[{ }^{3} \mathrm{H}\right] \text { ligand and unlabelled steroid }
\end{aligned}
$$

where, $\mathbf{B}=$ bound radioactivity, and the labelled steroid corresponds to the $\left[{ }^{3} \mathrm{H}\right]$ ligand used (from Milgrom et al., 1970).

\section{Statistical treatment}

All statistical procedures used were in accordance with the statistical principles described by Sokal and Rohlf (1980). Statistical manipulations were carried out on the universitybased mainframe computer using SAS Institute Inc. (IL, U.S.A.) software. Correlation analyses were conducted using the SAS PROC CORR procedure (Pearson's correlation coefficient, $r$ ).

\section{RESULTS}

The binding of $\left[{ }^{3} \mathrm{H}\right]$ testosterone to serial dilutions of plasma samples from animals of the various reproductive and social categories is depicted in Fig. 1. Plasma testosterone binding seemed to vary little between the various categories, with the exception of the parous and some lactating females. In these categories, elevated, but variable plasma testosterone binding was observed (Fig. 1).

In females, the percentage binding of testosterone to plasma substances increased significantly with an increase in plasma oestradiol-17 $\quad(r=0.81$; $P<0.001 ; N=14)$ and progesterone $(r=0.67$; $P<0.01 ; N=14$ ) concentrations. Males on the other hand, showed no correlation between plasma testosterone binding and circulating steroid concentrations. Also, androgen concentrations showed no significant relationship with the testosterone binding ability, with the exception of adult females $(r=0.57$; $P<0.05 ; N=15$ ).

The ability of several steroids to displace $[1,2,3,6,7$ $\left.{ }^{3} \mathrm{H}\right]$ testosterone and $\left[1,2,4,5,6,7-{ }^{3} \mathrm{H}\right] \mathrm{DHT}$ from plasma substances at $4^{\circ} \mathrm{C}$ is shown in Fig. 2. From this displacement it follows that no displacement occurred in male plasma (Fig. 2b, d), while androgens, progesterone and oestradiol-17 $\beta$ displaced $\left[1,2,3,6,7-{ }^{3} \mathrm{H}\right]$ testosterone and $\left[1,2,4,5,6,7-{ }^{3} \mathrm{H}\right] \mathrm{DHT}$ from plasma substances in female plasma (Fig. 2a, c). In female plasma, the order of competing efficiency against $\left[1,2,3,6,7-{ }^{3} \mathrm{H}\right]$ testosterone was as follows: testosterone, progesterone and oestradiol-17 $\beta$ (Fig. 2a). The order of competing efficiency against $[1,2,4,5,6,7-$ $\left.{ }^{3} \mathrm{H}\right] \mathrm{DHT}$, was: DHT, testosterone, oestradiol-17 $\beta$ and progesterone (Fig. 2c). Cortisol did not compete for binding sites against either testosterone or DHT (Fig. 2).

\section{DISCUSSION}

The positive correlation between the binding of testosterone to plasma and circulating ovarian steroid concentrations in adult females suggests that plasma binding ability is related to ovarian activity. Thus, the binding of androgens to plasma during lactation can be ascribed to follicular activity recorded in lactating spotted hyaenas (Van Jaarsveld et al., 1992). Also, increased plasma androgen binding associated with increases in circulating steroids could affect the biological availability of plasma androgens in adult females (Burke and Anderson, 1972; Baxter and Tyrrell, 1987). Assuming that the conventional dogma of the free hormone hypothesis is applicable 


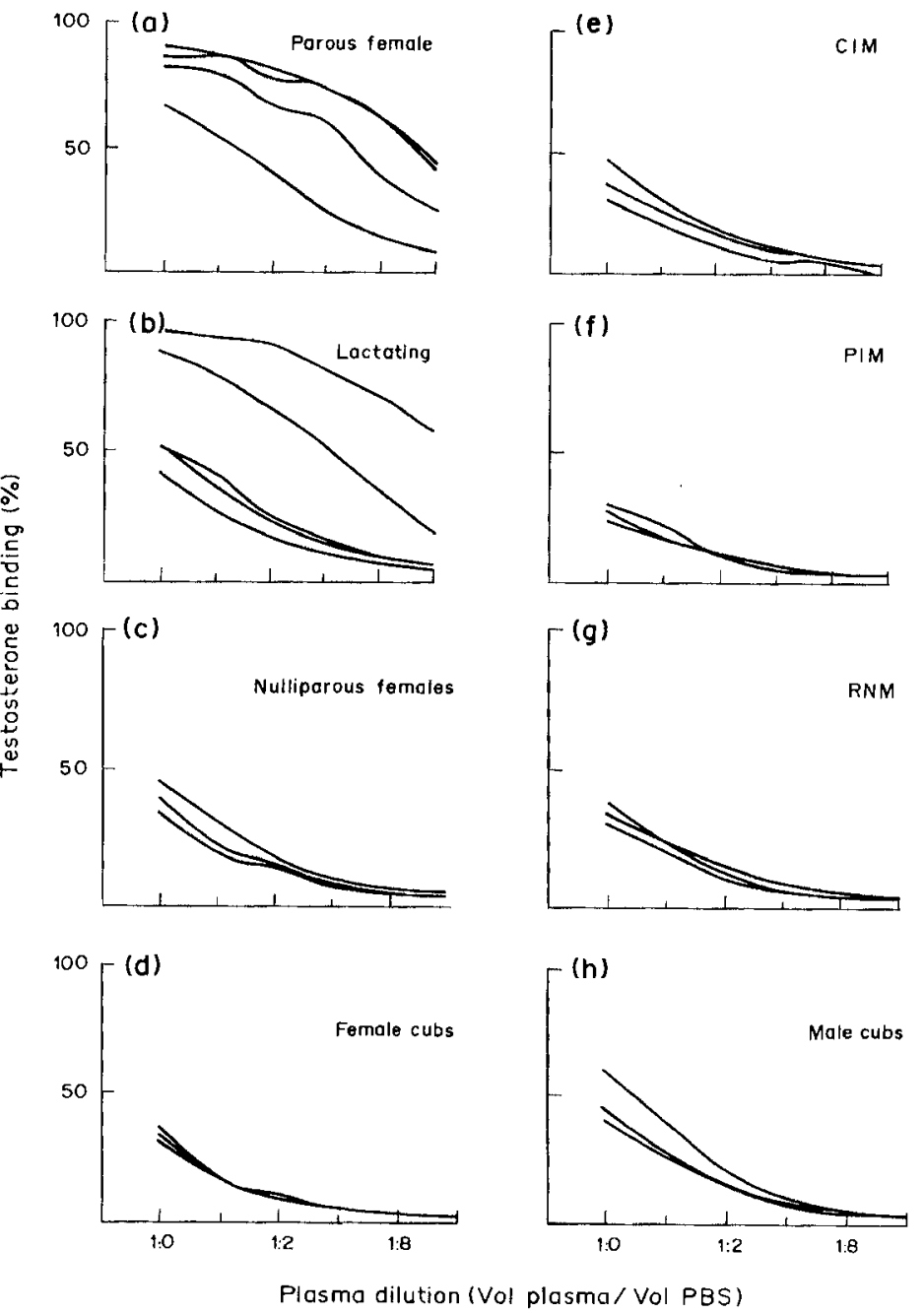

Fig. 1. Percentage testosterone binding in various categories of spotted hyaenas, showing the effect of serial plasma dilution on binding ability, the large variance in binding ability among adult females, as well as the higher testosterone binding ability of certain adult females when compared to all other categories. Females are grouped into reproductive categories and males into social categories following Matthews (1939) and Henschel and Skinner (1987), respectively. CIM, Central immigrant or mating males; PIM, peripheral immigrant males; RNM, resident natal males.

(Anderson, 1974), the binding of significant quantities of androgens would significantly reduce the available androgens in adult females, and would offer additional support for the hypothesis that female dominance in this species is not the result of high androgen concentrations in adult females (Van Jaarsveld and Skinner, 1987). The positive correlations between plasma testosterone binding and the circulating progesterone and testosterone concentrations in adult females, are probably an artefact of the high positive correlations that these biosynthetic precursors of oestradiol-17 $\beta$ (Baxter and Tyrrell, 1987) have with circulating oestradiol-17 $\beta$ concentrations in this species (Van Jaarsveld, 1990).

The strong affinity of both testosterone and DHT to spotted hyaena plasma is an indication that the substance (possibly a protein) involved is not cortisolbinding globulin (CBG), as $\left[{ }^{3} \mathrm{H}\right] \mathrm{DHT}$ does not bind to CBG (Anderson, 1974) and cortisol showed no competitive binding (Fig. 2). Also, the observed high binding affinity ( $\sim \mathrm{nM}$; Fig. $2 \mathrm{a}, \mathrm{c})$ rules out albumin as the androgen binding protein $(\sim 60 \mathrm{mM}$; Anderson, 1974), while the low competitive binding of oestradiol-17 $\beta$ (Fig. 2a, c) suggests that this substance specifically binds androgens. Therefore, these data indicate that the substance responsible for plasma androgen binding in female spotted hyaenas could be a specific androgen-binding globulin. This is in accord with the earlier demonstration that a strong androgen-binding protein occurs in the rabbit, dog, goat, and bull (Corvol and Bardin, 1973; Renoir et al., 1980; Pardridge, 1988). On the other hand, it differs from the sex hormone-binding globulin (SHBG) found in primates that strongly binds both androgens and oestradiol-17 $\beta$, as well as the lack of significant plasma androgen binding in rodents (Renoir et al., 1980). However, the most unusual 

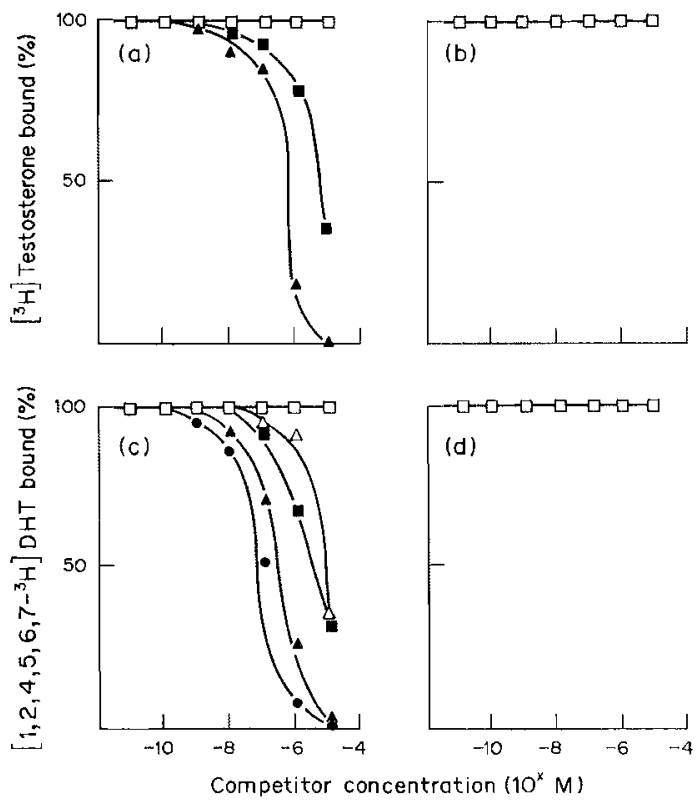

Fig. 2. Displacement ability of unlabelled DHT ( $)$, testosterone $(\boldsymbol{\Delta})$, progesterone $(\boldsymbol{\square})$, oestradiol-17 $\beta(\triangle)$, cortisol (O) of $\left[1,2,3,6,7-{ }^{3} \mathrm{H}\right]$ testosterone and $\left[1,2,4,5,6,7,{ }^{3} \mathrm{H}\right] \mathrm{DHT}$ from an androgen binding substance in the plasma of (a, c) a parous female, and $(b, d)$ a central immigrant male spotted hyaena. Protein concentrations used in binding activity experiments were $\sim 30-40 \mathrm{mg} / \mathrm{ml}$, as determined by absorbance at $280 \mathrm{~nm} . \square=100 \%$ binding for all competitors, except where specifically indicated otherwise.

observation which emerges from this investigation is the total lack of high affinity androgen binding in male plasma (Fig. 2b, d). This phenomenon needs further investigation.

The low androgen binding observed in all the spotted hyaenas (Fig. 1), including immature and male hyaenas, is probably the result of albumin binding, but this clearly represents a different mechanism than that responsible for the high affinity binding in certain adult females (Figs 1, 2).

Acknowledgements - We are indebted to the Board of Trustees of the National Parks Board of South Africa and their staff, as well as the Director and staff of the National Zoological Gardens, Pretoria, for their co-operation. This project was funded by the Foundation for Research Development and A. S. van Jaarsveld received Senior Charles Maberly Memorial Scholarships from the Transvaal Branch of the Wildlife Society of southern Africa.

\section{REFERENCES}

Anderson D. C. (1974) Sex-hormone-binding globulin. Clin. Endocr. 3, 69-96.

Baxter J. D. and Tyrrell J. B. (1987) The adrenal cortex. In Endocrinology and Metabolism (Edited by Felig P., Baxter J. D., Broadus A. E. and Frohman L. A.), pp. 511-650. McGraw-Hill, New York.
Burke C. W. and Anderson D. C. (1972) Sex-hormone-binding globulin is an oestrogen amplifier. Nature, Lond. 240, $38-40$

Corvol P. and Bardin C. W. (1973) Species distribution of testosterone-binding globulin. Biol. Reprod. 8, 277-282.

Fenske M. (1990) Protein binding of cortisol by means of competitive adsorption: application to cortisol binding by serum of sixteen eutherian mammals. Comp. Biochem. Physiol. 98A, 61-66.

Frank L. G., Davidson J. M. and Smith E. R. (1985) Androgen levels in the spotted hyaena Crocuta crocuta: the influence of social factors. $J$. Zool., Lond. 206, $525-531$.

Henschel J. R. and Skinner J. D. (1987) Social relationships and dispersal patterns in a clan of spotted hyaenas Crocuta crocuta in the Kruger National Park. S. Afr. J. Zool. 22, 18-24.

Kruuk H. (1972) The Spotted Hyena: a Study of Predation and Social Behavior. Chicago University Press.

Lindeque M. and Skinner J. D. (1982) Fetal androgens and sexual mimicry in spotted hyaenas (Crocuta crocuta). $J$. Reprod. Fert. 65, 405-410.

Matthews L. H. (1939) Reproduction in the spotted hyaena, Crocuta crocuta (Erxleben). Phil. Trans. R. Soc. (B) 230, $1-80$.

Milgrom E., Atger M. and Baulieu E.-E. (1970) Progesterone in uterus and plasma. IV-Progesterone receptor(s) in guinea pig uterus cytosol. Steroids 19, 741-754.

Pardridge W. M. (1985) Selective delivery of sex steroid hormones to tissues by albumin and sex hormone-binding globulin. Oxf. Rev. Reprod. Biol. 10, 237-292.

Racey P. A. and Skinner J. D. (1979) Endocrine aspects of sexual mimicry in the spotted hyaena, Crocuta crocuta. J. Zool., Lond. 187, 315-326.

Reinard T, and Jacobson H.-J. (1989) An inexpensive small volume equilibrium analysis system for protein ligand binding assays. Analyt. Biochem. 176, 157-160.

Renoir J. M., Mercier-Bodard C. and Baulieu E. (1980) Hormonal and immunological aspects of the phylogeny of sex-steroid binding plasma protein. Proc. natn. Acad. Sci. U.S.A. 77, 4578-4582.

Sokal R. R. and Rohlf F. J. (1980) Biometry. W. H. Freeman, San Francisco.

Van Aarde R. J. and Skinner J. D. (1986) Reproductive biology of the male Cape porcupine, Hystrix africaeaus tralis. J. Reprod. Fert. 76, 545-552.

Van Jaarsveld A. S. (1988) The use of Zoletil for the immobilization of spotted hyaenas. S. Afr. J. Wildl. Res. 18, 65-66.

Van Jaarsveld A. S. (1990) Endocrine correlates of social development in the spotted hyaena (Erxleben). PhD thesis, University of Pretoria.

Van Jaarsveld A. S. and Skinner J. D. (1987) Spotted hyaena monomorphin: an adaptive "phallusy"? $S . A f r . J$. Sci. 83, 612-615.

Van Jaarsveld A. S. and Skinner J. D. (199la) Plasma androgens in spotted hyaenas (Crocuta crocuta): influence of social and reproductive development. J. Reprod. Fert. 93, 195-201.

Van Jaarsveld A. S. and Skinner J. D. (1991b) Plasma androgen concentrations in initial samples from spotted hyaenas immobilized with Zoletil (CI-744) reflect hormonal status estimated by GnRH challenge and immobilization stress response. $S$. Afr. J. Zool, 26, 1-5.

Van Jaarsveld A. S., Skinner J. D. and Lindeque M. (1992) Morphological and steroidogenic assessment of ovarian activity during lactation in the spotted hyaena (Crocuta crocuta). J. Zool. Lond. 226, 31-46. 